\title{
MACRINA THE YOUNGER - THE INVENTED SAINT
}

According to the recent studies on early monasticism and asceticism Macrina the Younger was one of the most important persons of $4^{\text {th }}$ century Christianity in Pontus. Scholars treat Vita Sanctae Macrinae (hereinafter cited as VSM) written by her brother Gregory of Nyssa as a source of information about her character and achievements. A.M. Silvas begins a book about Macrina with the following statement: "The holy woman known in Christian tradition as Saint Macrina the Younger (327-379) was the descendant of resolutely Christian forbears, the firstborn among some famous siblings, and the leader of a family outstanding for its contribution to Christian history, piety, and culture"1. Further, "Macrina became a spiritual mother and teacher to her own mother, Emmelia, and to each of her four brothers" (including Basil the Great). She is considered also "the guide and teacher of the virgins she directed in her monastery"3, "a pioneering monastic founder"4. S. Elm stressed in her study about feminine asceticism in Late Antiquity: "Because of her significantly earlier experience and her uninterrupted presence, Macrina may well have been the dominant figure at Annesi; her share in developing what is known as Basilian monasticism ought not to be underrated"5.

In my opinion, in order to establish who Macrina actually was, first of all we need to analyse the sources that speak about her, determine their literary genre and compare them with other sources.

A.M. Silvas, Macrina the Younger. Philosopher of God, Brepols Publishers, Turnhout 2008, 1.

A.M. Silvas, Macrina the Younger, 2.

L.F. Mateo-Seco, Vita Macrinae, in The Brill Dictionary of Gregory of Nyssa, eds. L.F. MateoSeco - G. Maspero, Brill, Leuven 2010, 469.

4 J. McGuckin, Macrina, in Encyclopedia of Monasticism, ed. W.M. Johnston, Taylor \& Francis, Chicago - London 2000, vol. 2, 801.

5 S. Elm, Virgins of God: The Making of Asceticism in Late Antiquity, Clarendon Press, Oxford 1994, 104. 


\section{WRITINGS ABOUT MACRINA THE YOUNGER}

Macrina the Younger can be found in four Ancient writings: Vita Sanctae Macrinae, letter 19, dialogue De anima et resurrectione by Gregory of Nyssa and epitaph 120 by Gregory of Nazianzus. In order to assess the information they contain it is necessary, above all, to establish their literary genre, because depending on it we can treat the events they describe as historical facts or not.

\section{Vita Sanctae Macrinae by Gregory of Nyssa}

VSM is the most extensive Ancient writing about Macrina. It has been translated many times and widely studied; lately, it aroused special interest of researchers of early Christian spirituality and feminist theologians looking for meaningful feminine characters in Antiquity. I do claim that VSM is neither a philosophical biography ${ }^{6}$ as Maraval wanted ${ }^{7}$, nor a family chronicle, as Silvas called it ${ }^{8}$, but it is a hagiography. Although Barnes thinks that "hagiography was never a literary genre in the strict definition of that term", it has its characteristic features. What makes hagiography distinct from history is, according to $\mathrm{H}$. Delehaye, the religious character of the writing and the purpose of edification ${ }^{10}$. At the beginning of VSM,

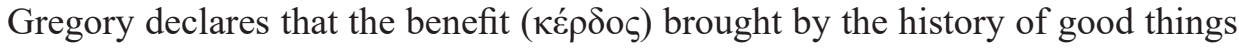

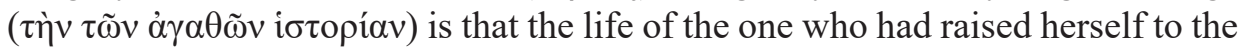

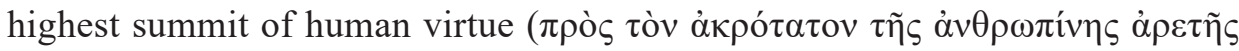

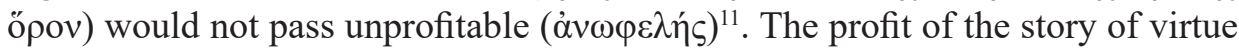
is, of course, spiritual and it does not need real events or even real persons to be attained. We can see the same purpose also in the $2^{\text {nd }}$ century influential Martyrium Polycarpi, belonging to the so-called Smyrnean hagiography ${ }^{12}$. The explicit aim

6 The scope of philosophical biography was to present the life and doctrine of a philosopher, see G.J.M. Bartelink, Introduction, in Vie d'Antoine, ed. G.J.M. Bartelink, SCh 400, Les éditions du Cerf, Paris 1994, 47-48.

7 P. Maraval, Intoduction, in Vie de sainte Macrine, ed. P. Maraval, SCh 178, Les éditions du Cerf, Paris 1971, 21-23 and 92.

8 A.M. Silvas, Macrina the Younger, op. cit., 103.

9 T.D. Barnes, Early Christian Hagiography and Roman History, Mohr Sieback, Tübingen 2010, 237.

10 H. Delehaye, Les légendes hagiographiques, Société des Bollandistes, Bruxelles 1906, 2: "Pour être strictement hagiographique, le document doit avoir un caractère religieux et se proposer un but d'édification. Il faudra donc réserver ce nom à tout monument écrit inspiré par le culte des saints, et destiné à le promouvoir. Ce qu'il importe d'accentuer dès le début, c'est la distinction entre l'hagiographie et l'histoire".

11 Gregory of Nyssa, Vita Sanctae Macrinae, ed. V. Woods Callahan, Brill, Leiden 1963, GNO 8/1, 371.16-23.

12 For dating of the text and references to it in later Christian literature, see two articles by J.M. Kozłowski, Pionius Polycarpi imitator: References to Martyrium Polycarpi in Martyrium 
of this writing is that "we may become Polycarp's followers" (ǐ $\alpha \mu \mu \eta \eta \alpha \grave{~ \kappa \alpha i ̀ ~}$

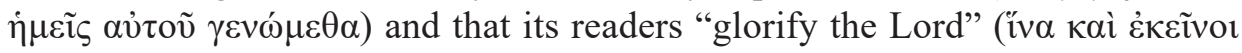

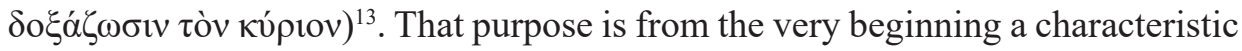
feature of Christian hagiography.

$V S M$ was not the first hagiography of an ascetic and non-martyr. The first was Vita Antonii by Athanasius of Alexandria (hereinafter cited as VA). VSM clearly follows the model of the saint established by $V A^{14}$. Gregory's Macrina in many details mimics the characteristics and behaviour of Athanasius' Antony. Both Antony ${ }^{15}$ and Macrina ${ }^{16}$ were born to Christian families, were raised on the Bible, isolated from the influence of culture and Pagan habits. On the other hand, the letters by Antony and the dialogue De anima and resurrectione show our heroes from a completely different perspective. Scholars agree that his letters prove that Antony must have read with understanding the writings by Origen and Gnostics ${ }^{17}$, and Macrina in the dialogue not only mentions philosophers by name ${ }^{18}$, but engages in a discussion with Gregory on the highest scientific level (in the Ancient sense) using dialectic and rhetoric. So it seems that isolation from culture is nothing more than a literary topos.

Both saints lived very simple lives from very early childhood ${ }^{19}$. D. Brakke noticed the resemblance between the behaviour of young Antony (so Macrina as well) and the lifestyle of young Mary as Athanasius described it in his first Letter to Virgins ${ }^{20}$. The characteristic feature of both is peace and total absence of corporal sensations ${ }^{21}$. It is an ideal that can be aspired to, but unattainable on earth.

Pionii, "Science et Esprit" 67 (2015), 417-434; and Tanto perfusus est sanguine, ut... Dependence of Passio Perpetuae 21,1-3 upon Martyrium Polycarpi 14,2 and 16,1, "Eirene. Studia Graeca et Latina" 52 (2016), 387-395.

H. Delehaye, Les passions des martyrs et les genres littéraires, "Subsidia Hagiographica" 13, Bruxelles 1966², 15-46.

13 Ecclesiae Smyrnensis de martyrio S. Polycarpi epistola circolaris I 2, PG 5, 1029B; XX 1; PG $5,1044 \mathrm{C}$.

14 Gregory of Nazianzus (Oratio 21, 5 (In laudem Athanasii); PG 35, 1088A) testifies that VA was known among Cappadocians.

$15 V A$, SCh 400, 130.

16 VSM, GNO 8/1, 373-374.

17 S. Rubenson, Letters of St. Antony: Monasticism and the Making of A Saint, Trinity Press Int'1, Minneapolis 1995, 59-88; D. Brakke, Athanasius and the Politics of Asceticism, Oxford University Press, Oxford 1995, 256-258; E. Wipszycka, Drugi dar Nilu. Czyli o mnichach i klasztorach w późnoantycznym Egipcie, Tyniec. Wydawnictwo Benedyktynów, Kraków 2014, 68-75 (the book by Prof. Wipszycka is being translated into English and is going to be published in 2018).

18 Gregory of Nyssa, De anima et resurrectione, ed. A. Spira, Brill, Leiden-Boston 2014, GNO 3/3, 8 and 33-34.

$19 V A, \mathrm{SCh} 400,130 ;$ VSM, GNO 8/1, 374 and 376.

20 D. Brakke, Athanasius and the Politics of Asceticism, op. cit., 254.

21 VA, SCh 400, 172-174; VSM, GNO 8/1, 382. 
Both authors of the Lives were aware of its unattainableness, so Athanasius calls

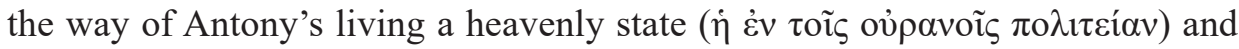

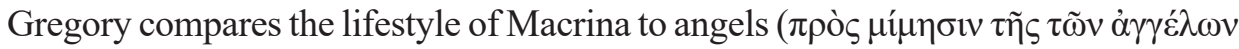
$\delta ı \alpha \gamma \omega \gamma \tilde{\eta} \varsigma$ ). Bartelink analysed the biblical references in VA (more than 200) proving that the ideal personified by Antony (and Macrina as she follows Antony's model) had its deep biblical roots ${ }^{22}$.

The descriptions of the last days, death and funeral of Antony and Macrina are similar. In both cases they are long, detailed, and contain speeches of the heroes, kind of testaments for their companions, called farewell speeches ${ }^{23}$. Festugière analysed the last prayer of Macrina from VSM and stated that it was a noble literary composition that had nothing to do with historical probability ${ }^{24}$.

In order to achieve its intended purpose (which is edification of the readers) hagiography used fictional elements from the very beginning of the genre. In $V A$ and $V S M$, even the emphasis present in both writings that the author was an eyewitness of the saint's life ${ }^{25}$ is a literary topos and has little to do with reality. Brakke noticed "the paucity of evidence for actual contact between Athanasius and the historical Antony"26, Wipszycka questions the probability that Athanasius knew Coptic and it was the only language he could use to talk with Antony or with the witnesses of his life ${ }^{27}$. Regarding Gregory of Nyssa, he himself admitted in VSM that he did not see his sister for many years ${ }^{28}$ and he knew her miracles only from the accounts of others ${ }^{29}$.

Regarding Antony we can verify some events described in $V A$ and some of them are obviously fictitious ${ }^{30}$. Heussi thinks that the entire episode from $V A$ 46, where Antony comes to Alexandria to support persecuted Christians, is fake ${ }^{31}$. Wipszycka believes that Antony could have been in Alexandria, but she considers the ban on letting ascetics into a court anachronistic as ascetics were not a separate, distinctive group at that time ${ }^{32}$. She also thinks it was impossible that Antony served

22 G.J.M. Bartelink, Introduction, SCh 400, 48-53.

23 M. Alexandre, Á propos du recit de la mort d'Antoine. L'heure de la mort dans la littérature monastique, in Le temps chrétien de la fin de l'Antiquité au Moyen Age (IIIe-XIIIe siecles), ed. J.M. Leroux, CNRS Éditions, Paris 1984, 263-282.

24 A.J. Festugière, Vraisemblance psychologique et forme littéraire chez les anciens, "Philologus" 102 (1958), 38.

25 VA, SCh 400, 126-128; VSM, GNO 8/1, 371.9-16.

26 D. Brakke, Athanasius and the Politics of Asceticism, op. cit., 206.

27 E. Wipszycka, Drugi dar Nilu, op. cit., 59.

28 VSM, GNO 8/1, 387.6-9.

29 VSM, GNO 8/1, 404.20-406.9; 410.7-413.16.

30 T.D. Barnes (Early Christian Hagiography and Roman History, 160) calls VA a fictitious hagiography and an imaginative composition.

31 K. Heussi, Der Ursprung des Mönchtums, Scientia Verlag, Tübingen 1936, 94-96.

32 Drugi dar Nilu, op. cit., 90-91. 
Christians who worked in mines/quarry $(\mu \varepsilon \dot{\tau} \tau \alpha \lambda \lambda \alpha)$ as there were no such $\mu \varepsilon \dot{\tau} \tau \alpha \lambda \lambda \alpha$ near Alexandria ${ }^{33}$.

In $V A$ 81, Antony receives a letter from Constantine and his sons, and replies with reluctance advising them how to hold power. We have the testimony of Sozomenus who presented a different version of the event. According to Historia ecclesiastica II 31, it was Antony who first wrote to the emperor in the defence of Athanasius. The letter of Constantius was only a reply; moreover, he declined to recall Athanasius from his exile. Historians have no doubt that the version of Sozomenus was a true one ${ }^{34}$. So, Athanasius intentionally described the exchange of letters between Antony and Constantine at variance with the reality. And it is not a surprise, if we remember the purpose of hagiography: "the primary social function of the Athanasian Antony is to inspire imitation" 35 , "Athanasius did not describe what happened, but what should have happened"36, "hagiographical work may be historical, but it is not necessary. It can don all literary genres suitable for glorifying the saints from official relation modified for usage of the faithful to the exuberant poetical work, with no reference to the reality" ${ }^{37}$.

All of the above quoted statements apply to VSM as well as to VA. Some scholars already noticed that what Gregory of Nyssa wrote about Macrina is typical of a literary construct. S. Elm pointed out that the description of Macrina's earliest years is "stylized and subject to rhetorical conventions" ${ }^{38}$. P. Maraval claimed that Gregory knew how to distort the reality in order to make his story more believable ${ }^{39}$ and that the description of Macrina's community in Annisa is very rhetorical ${ }^{40}$. G. Luck suggested that he used the technique of a novelist to dramatize a very real event ${ }^{41}$. A. Cameron went even farther: "Though the temptation to read the Life of Macrina as a real portrait has been strong, especially among those interested in women in Late Antiquity, for Gregory, the figure of Macrina is a literary trope" ${ }^{\prime 2}$.

33 Ibid., 89-90.

34 K. Heussi, Der Ursprung des Mönchtums, op. cit., 91-93; T.D. Barnes, Athanasius and Constantius: Theology and Politics in the Constantinian Empire, Harvard University Press, Cambridge 2001, 96-97.

35 D. Brakke, Athanasius and the Politics of Asceticism, op. cit., 258.

36 E. Wipszycka, Wstęp, in Atanazy Aleksandryjski, Żywot świętego Antoniego, Instytut Wydawniczy PAX, Warszawa 1987, 39.

37 H. Delehaye, Les légendes hagiographiques, op. cit., 2.

38 S. Elm, Virgins of God, op. cit., 47.

39 P. Maraval, Encore les frères et soeurs de Grégoire de Nysse, "Revue d'histoire et de philosophie religieuses" 60 (1980), 163.

40 P. Maraval, Intoduction, SCh 178, 54.

${ }^{41}$ G. Luck, Notes on the Vita Macrinae, in The Biographical Works of Gregory of Nyssa. Proceedings of the Fifth International Colloquium on Gregory of Nyssa, Mainz, 6-10 September 1982, ed. A. Spira, The Philadelphia Patristic Foundation, Cambridge 1984, 26.

42 A. Cameron, Dialoguing in Late Antiquity, Washington DC 2014, <http://chs.harvard.edu/CHS/ article/display/5495> (24.2.2017). 


\section{Letter 19 by Gregory of Nyssa}

Letter 19 by Gregory of Nyssa alludes to the circumstances of his election to the bishop of Sebastea ${ }^{43}$, and according to its title should speak about the life of Macrina. Actually, we do not find there any information about her. The "description" of Macrina consists of quotations from the Bible, epithets that in the Bible refer to God. Using the verbs of Psalms, Gregory calls her a strong tower, a shield of favour, a fortified city and an utter assurance ${ }^{44}$. Moreover, Macrina is described as devoid of any corporal sensation; she knew no distinction between night and

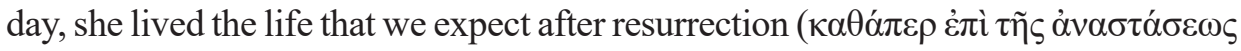
$\left.\dot{v} \pi \mathrm{o} \pi \tau \varepsilon v v_{0} \mu \varepsilon v\right)$. Gregory finished the portrayal with the meaningful rhetorical question: "How anyone could present to the eyes the reality that transcends any verbal description?" 45

The following description of Gregory's arrival to his sister ${ }^{46}$ is similarly rhetorical and could not be applied to a real person. Especially in the mouth of a Christian comparing somebody to a source of water ( $\tau \iota v \alpha \kappa \rho \eta ́ v \eta v)$ and calling her "the entire good/every good" ( $\pi \tilde{\alpha} v \dot{\alpha} \gamma \alpha \theta$ óv) must have sounded as a blasphemy if it concerned a real human being. So, the letter seems to be a rhetorical work, not a documentation as Silvas wanted ${ }^{47}$.

Letter 19 has a strange title: "To a certain John on certain subjects, especially on the way of life and the character of such a sister of him Macrina (Прó $\tau \tau \imath \alpha$

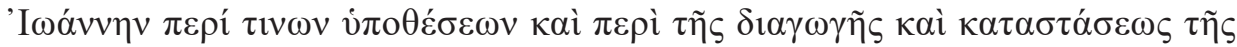

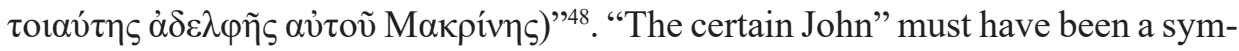
bolic person and not a real one. Addressing the letter "to the certain John" proves in my opinion that the writing was not to be a personal letter, but was thought by Gregory as a circular ${ }^{49}$.

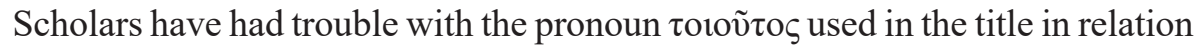
to Macrina. It can mean "such wise", but its first meaning is "such as this" and according to Liddell \& Scott it can also refer to what goes before. G. Pasquali

43 F. Diekamp (Die Wahl Gregors von Nyssa zum Metropoliten von Sebaste im Jahre 380, "Theologische Quartalschrift" 90 (1908), 384) states that the letter 19 is the only source that says anything about the election.

${ }^{44}$ Gregory of Nyssa, Epistula 19, 6-8, ed. G. Pasquali, Brill, Leiden 1959, GNO 8/2, 64.14-65.2.

45 Epistula 19, 9; GNO 8/2, 65.3-9.

46 Epistula 19, 10; GNO 8/2, 65.10-23.

47 A.M. Silvas, in Gregory of Nyssa, The Letters. Introduction, Translation and Commentary, Brill, Leiden - Boston 2007, 174.

48 GNO 8/2, 62.2-4.

49 A.M. Silvas (in Gregory of Nyssa, The Letters, 173) points out also the formal language of the letter: "He clearly intended this letter as a kind of bulletin of his affairs to someone well placed in church affairs, meant to correct any misinformation". 
commented it shortly: "non intellego" 50 ; R. Crisculo translated it into Italian with the word "tal" ${ }^{\prime}$; P. Maraval into French with "célèbre"52.; and A. Silvas just omi-

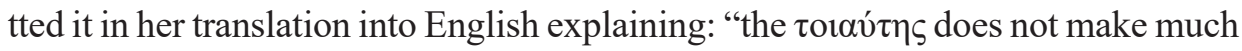
sense" ${ }^{53}$. However, I can see a reason for its use.

We cannot date Gregory's writings with absolute certainty as we have no external evidence to confirm the dating, but it is possible that all four writings about Macrina (including epitaph 120 by Gregory of Nazianzus) were written more or less at the same time. It is possible that VSM was the first writing about Macrina at all, and letter 19 was to be a kind of advertisement of VSM. It is important to realise that before VSM and letter 19 were written nobody had ever mentioned Macrina - neither Gregory of Nyssa himself, nor Basil, nor Gregory of Nazianzus. VSM is probably the first writing about Macrina, so the pronoun "such" in the advertising letter 19 specifies the person, referring to what goes before (VSM).

\section{De anima et resurrectione by Gregory of Nyssa}

Although a lot of prominent scholars claimed that De anima et resurrectione is a record of a real conversation between Gregory of Nyssa and Macrina ${ }^{54}$, it is impossible for many reasons, for many other-improbable. First of all, the dialogue occupies 123 pages in GNO edition - it is physically impossible to read or deliver it in one afternoon as VSM suggests it was ${ }^{55}$. Secondly, there are so many contradictions between VSM and De anima et resurrectione regarding the circumstances of the conversation (I will point them out below) that it is hardly believable it happened in reality.

On the other hand, a dialogue means not only conversation between two people but has been for ages an acknowledged literary genre ${ }^{56}$. A special type of that genre is a philosophical dialogue ${ }^{57}$, associated above all with Plato. It is difficult, if not impossible, to harmonise Plato's Socrates with the one we know from other sources

${ }^{50}$ GNO 8/2, 62 .

51 Gregorio di Nissa, Epistole, trad. R. Crisculo, Città Nuova, Napoli 1981, 123.

52 Grégoire de Nysse, Lettres, trad. P. Maraval, SCh 363, Les éditions du Cerf, Paris 1990, 243.

53 A.M. Silvas, The Letters, op. cit., 174, footnote 275.

54 M. Hoffmann, Der dialog bei den christlichen Schriftstellern der ersten vier Jahrhunderte, Akademie-Verlag, Berlin 1966, 130 and 135; B.R. Voss, Der dialog in der frühchristlichen Literatur, Wilhelm Fink Verlag, München 1970, 175; J. Quasten, Patrology, Resources for Christian Living, Allen 1986, vol. 3, 261; J.M. Sauget, Macrina la Giovane, in Bibliotheca Sanctorum, vol. 8, Città Nuova, Roma 1996, 457; I. Ramelli, Saggio introduttivo, in Gregorio di Nissa, Sull'anima et resurrezione, RCS Libri, Milano 2007, 7; L.F. Mateo-Seco, Macrina, in Dictionary of Gregory of Nyssa, op. cit., 473.

55 GNO 8/1, 389-391.

56 V. Hösle, Der philosophische Dialog: Eine Poetik und Hermeneutik, C.H. Beck, München 2006, 32.

57 V. Hösle, Der philosophische Dialog, op. cit., 54. 
(Xenophon, Aristophanes) ${ }^{58}$, so it is generally assumed that Plato transmitted his own ideas through the personage of Socrates. And the same happened in the literary construction by Gregory of Nyssa, written in accordance with the canons of the genre - a philosophical dialogue. Therefore, I have no doubts that Macrina serves here as "a mouthpiece for Gregory's theology" 59 and the dialogue is not a record of a real conversation. As Cameron stated: "Gregory's use of the dialogue form in On the Soul is clearly a deliberate literary choice, carefully adopting a Platonic model" 60 .

It is worth stressing that at the time when Gregory was writing, a dialogue as a literary genre already had a long and respectable tradition in Christian literature, starting with apologetic dialogues (Ariston of Pella, Justin and Minutius Felix) to the dialogues which Hoffman called dogmatic-polemic and philosophical ${ }^{61}$ (Origen, Gregory Thaumaturgos, and above all Methodius of Olympus). The purpose of those writings was apologetic and polemic; none of them was intended to record a real conversation but to convince a sophisticated, well-educated reader that Christianity is a true and best philosophy. I claim that De anima et resurrectione has the same polemical aim: to defend Gregory's own concepts on the soul, resurrection and apokatastasis. We can, of course, ask why he chose his sister as a "mouthpiece", but that is a subject for independent research and actually has been already widely discussed ${ }^{62}$.

\section{The epitaph 120 by Gregory of Nazianzus}

The fourth and last Ancient writing about Macrina is an epitaph by Gregory of Nazianzus. It suggests that Macrina had been hidden and unknown before VSM made her famous. The epitaph reads as follow:

"Me, the dust, I hold the radiant virgin, if you hear about certain

Macrina - the first-born of great Emmelia,

58 C. Kahn, Plato and the Socratic Dialogue: The Philosophical Use of a Literary Form, Cambridge University Press, Cambridge 1996, 1-35.

59 E.A. Clark, Holy Women, Holy Words: Early Christian Women, Social History and the "Linguistic Turn", "Journal of Early Christian Studies" 6 (1998), 427; B. Altaner, Précis de patrologie, Editions Salvator, Paris 1961, 438; P. Maraval, Intoduction, SCh 178, 36; A. Momigliano, The Life of St. Macrina by Gregory of Nyssa, in On Pagans, Jews, and Christians, Wesleyan, Middletown 1987, 208; D. Krueger, Writing and the Liturgy of Memory in Gregory of Nyssa's Life of Macrina, "Journal of Early Christian Studies" 8 (2000), 488.

60 A. Cameron, Dialoguing in Late Antiquity, op. cit.

${ }_{61}$ M. Hoffmann, Der dialog, op. cit., 57-159.

62 E.A. Clark, Holy Women, Holy Words, op. cit., 413-430; D. Krueger, Writing and the Liturgy of Memory, op. cit., 483-510; W. E. Helleman, Cappadocian Macrina as Lady Wisdom, "Studia Patristica" 37 (2001), 86-102; S. Wessel, Memory and Individuality in Gregory of Nyssa's De anima et resurrectione, "Journal of Early Christian Studies" 18 (2010), 369-392; L. Karfiková, Gregory of Nyssa, Witness of Macrina's Life and Death, "Theologica Olomucensia" 14 (2013), 15-26; A. Cameron, Dialoguing in Late Antiquity, op. cit. 
who hid herself from the eyes of men, yet now she is on

every tongue and she has achieved better fame" ${ }^{93}$.

The poetry as such could, of course, refer to real persons and historical events, but it is not necessary for its literary construction.

Summing up, all four writings about Macrina were written according to the rules of different literary genres: hagiography, rhetoric, dialogue, epitaph. Those genres have their specific purposes (edification, polemics, apology, honouring), but none of them is aimed at recounting real events and describing actual people. Of course, they can do that if it helps to achieve an aim intended by the author, but they can also distort reality and use fictitious elements in order to edify the reader (hagiography - VSM), present the point of view of the author (rhetoric letter 19), fight doctrines of the opponents (philosophical dialogue - De anima et resurrectione), or honour somebody (epitaph 120). So, we cannot trust the information they contain, but we need to confront them with external sources.

\section{CONTRADICTIONS IN THE WRITINGS ABOUT MACRINA AND OTHER SOURCES}

Incoherencies and contradictions in the very writings about Macrina and between those writings and other sources are the most important evidence that none of the Macrina writings describes the real history; moreover, none of them pretended to do so. I will list here only some of the most important contradictions, but there are a lot more contradicting details.

\section{Two Macrinas}

The most conspicuous incoherence we face while thinking about Macrina is a huge difference between two Macrinas: one from VSM and the other from De anima et resurectione. In VSM Macrina was educated by her Christian parents and from the very beginning she read only Bible; also when she grew up she and her companions cared only about divine things and unceasing prayer ${ }^{64}$. Meanwhile, in De anima et resurectione Macrina not only names Pagan philosophers ${ }^{65}$, but she leads the discussion on the highest scientific level - scientific of course in the Ancient meaning; so, it is a philosophical discussion full of dialectic and rhetoric. If we treated both writings as describing historical person, we would have to admit that Macrina was schizophrenic or that there were two different Macrinas. And yet, Macrina was not schizophrenic nor Gregory was intellectually disabled, but

${ }_{63}$ Epitaphium 120, PG 38, 75-76= epigram VIII 163, in Anthologie palatine, ed. P. Walz, Les Belles Lettres, Paris 1944.

${ }^{64}$ GNO 8/1, 382.15-18.

65 GNO 3/3, 8 and 33-34. 
Macrina constitutes in both writings a deliberate and elaborate literary construct. In VSM she is a model of a saint ascetic, simple and focused on virtuous life. In the dialogue she is a philosopher, teacher and authority on elevated philosophical and theological topics.

\section{Circumstances of the last meeting}

All three writings about Macrina by Gregory of Nyssa describe the last meeting of the siblings. In each of them the author himself gives a different reason why he decided to visit his sister. In De anima et resurrectione he comes to Macrina in

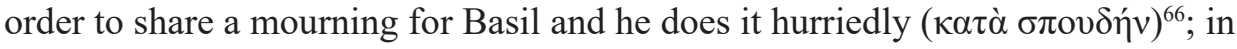
VSM he just wanted to visit her and it was nine months after Basil' death ${ }^{67}$. According to VSM, during the journey he had a vision which he interpreted as a harbinger of disaster and only after that he learned that Macrina was ill ${ }^{68}$. By contrast, in letter 19 he said that while he was in Cappadocia he was alarmed by some rumours about her and that is why he decided to go to Pontus ${ }^{69}$.

Those differences are understandable if we remember a different genre and different purpose of each of the writings. In De anima et resurrectione the death of Basil serves as a pretext for discussion about death, resurrection and soul's immortality. In the VSM Gregory "just felt like visiting Macrina," which was to stress his close relationship with his sister and make credible his story about her. In letter 19, Gregory justifies himself why he had left his own diocese endangered by many heresies (Cappadocia) and went on a journey to home (Pontus).

Farther, Gregory himself gives us different information on the time that passed from his previous meeting with Macrina. In VSM he counted the years and the

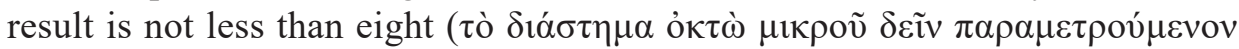
Ě $\tau \varepsilon \sigma v)^{70}$; by contrast, in letter 19 he affirms that he saw his beloved sister for the

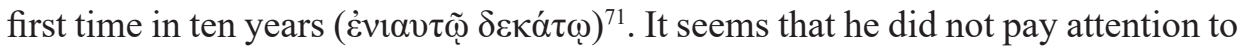
chronological details as none of the writings was intended to present historical events.

\section{Number of siblings}

In one and the same writing, namely VSM, Gregory seems to give two versions of the number of Emmelia's children. First, he says that the mother had four sons

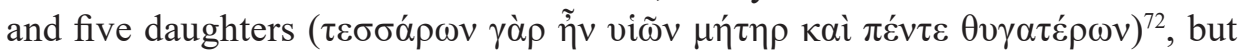

${ }^{66}$ GNO 3/3, 1.4-8.

${ }^{67}$ GNO 8/1, 385.22-387.3.

${ }_{68}$ GNO 8/1, 387.19-389.6.

69 GNO 8/2, 65.10-14.

70 GNO 8/1, 387.3-9.

71 GNO 8/2, 65.19-21.

72 GNO 8/1, 376.18-19. 
when Emmelia is praying on the deathbed, she speaks about Macrina and Peter in such a way that a lot of scholars understand as if there were ten children: "To you,

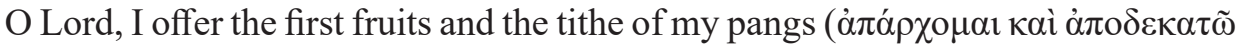

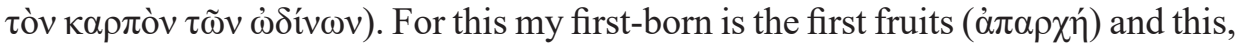

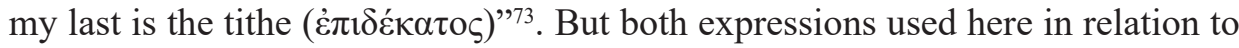
children ( $\dot{\alpha} \pi \alpha \rho \chi \eta ́$ and $\dot{\pi} \pi \mathrm{\imath} \delta \dot{\varepsilon} \kappa \alpha \tau \sigma \nu)$ constitute in the Bible technical terms meaning the offering for $\mathrm{God}^{74}$. Drawing the conclusion that Emmelia must have had ten children, but one of them died in infancy ${ }^{75}$, seems absurd to me. However, I would stress that even the number of nine children is rather symbolic (nine fruits of the Holy Spirit from Ga 5, 22-23) as we have no external testimonies to confirm it. Gregory of Nazianzus said only that all of the children of Emmelia and Basil led virtuous life, though some of them were priests, some virgins and some were married $^{76}$.

\section{Basil's conversion}

The biggest amount of incoherencies concerns the conversion of Basil, namely his decision to start leading ascetic life. It was a crucial moment of his career as the Ancients attached a lot of significance to the master-pupil relationship. According to VSM, when Basil returned to Annisa after his studies in Athens, he was proud and haughty because of his rhetorical skills. Then, Macrina "persuaded him

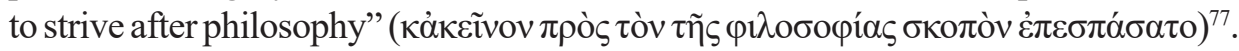
Basil himself left us two different (not exclusive) stories about his own conversion. In letter 1 addressed to Eustathius the philosopher, identified by Garamond with Eustathius of Sebastea ${ }^{78}$, Basil confessed that he had quitted his studies in Athens

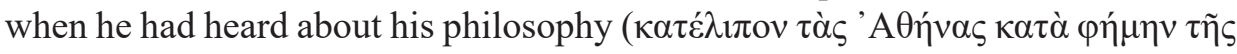

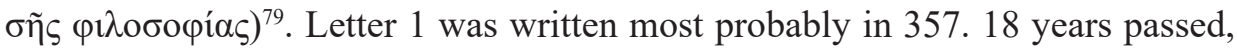
Eustathius many times signed different heretic confessions of the faith, and it was difficult even for Basil himself to admit that he had been so fascinated by his

3 GNO 8/1, 385.3-5.

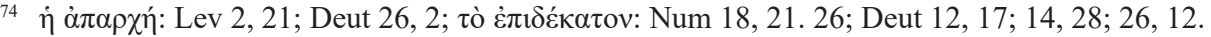

75 J.E. Pfister, A biographical note: The Brothers and Sisters of St. Gregory of Nyssa, "Vigiliae Christianae" 18 (1964), 113; P. Maraval, Encore les frères et soeurs de Grégoire de Nysse, op. cit., 162; A.M. Silvas, The Asketikon of St Basil the Great, Oxford University Press, Oxford - New York 2005, 65; A. Radde-Gallwitz, Basil of Caesarea. A guide to his life and doctrine, Eugene 2012, 22.

76 Gregory of Nazianzus, Oratio 43, 9 (In laudem Basilii Magni Caesareae in Cappadocia episcopi), op. cit., PG 36, 505.

77 GNO 8/1, 377.7-19.

78 J. Gribomont, Eustache le philosophe et les voyages du jeune Basile de Césarée, "Revue d'histoire ecclésiastique" 54 (1959), 116-120.

79 Basil the Great, Epistulae 1, ed. Y. Courtonne, Les Belles Lettres, Paris 1957, vol. 1, 3. 
person $^{80}$. In letter 223 written in 375 and addressed to the very same Eustathius of Sebastea Basil passed over his role as an inspirer of his asceticism and wrote:

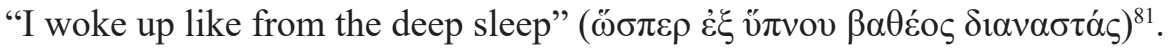

These are not the only versions of Basil's conversion that we can find in Ancient literature. A matter of inspiration seems to be then the case of utmost importance. Not without reason Rufinus wrote that it was Gregory of Nazianzus who literally forced Basil to lead a monastic life (ad monasterium manu injecta perduceret) ${ }^{82}$. Rufinus apparently disliked Basil and wanted to discredit him with such inversion of roles ${ }^{83}$. In reality, we know from letters by both Basil and Gregory of Nazianzus that it was Basil who was persuading his friend to lead an ascetic life (letters 2 and 14 by Basil). Gregory of Nazianzus promised to come to Basil, who was staying near the Iris river, but found various excuses in order not to (letter 1 by Gregory of Nazianzus).

\section{WRITINGS THAT DO NOT MENTION MACRINA}

If Macrina really was a pioneering monastic founder she should have appeared in the specific places in the specific writings, but she actually did not. I will point out at least the most obvious sources in which Macrina is absent, though she should have been present, if she had been the inspirer and the prominent representative of ascetic and monastic life in Pontus.

\section{Basil the Great}

Many scholars have been wondering why Basil never mentioned his sister Macrina not only in his ascetic writings, but also in any of his letters ${ }^{84}$. Basil did not say a word about Macrina in his letter 1 describing his conversion, although according to VSM it was Macrina who inspired him to the ascetic lifestyle ${ }^{85}$. He did not mention Macrina in his letter 207 describing the community in Annisa ${ }^{86}$

${ }^{80}$ F. Fatti, Monachesimo anatolico. Eustazio di Sebastia e Basilio di Cesarea, in Monachesimo orientale. Un'introduzione, ed. G. Filoramo, Morcelliana, Brescia 2010, 71.

81 Basil the Great, Epistulae 223, 2, ed. Y. Courtonne, vol. 3, 10.

82 Rufinus of Aquileia, Historia Ecclesiastica II 9, PL 21, 518B.

83 T.G. Kardong, Who was Basil's mentor? Part 1, "American Benedictine Revue" 60 (2009), 185.

84 P. Maraval, Intoduction, SCh 178, 36-37 and 53; S. Elm, Virgins of God, op. cit., 82; J.R. Pouchet, Basile le Grand et son univers d'amis d'après sa correspondance: une stratégie de communion, Institutum Patristicum Augustinianum, Roma 1992, 92, footnote 3; A.M. Silvas, Macrina the Younger, op. cit., 37; A. Radde-Gallwitz, Basil of Caesarea, op. cit., 28.

85 VSM, GNO 8/1, 377.7-19.

${ }^{86}$ I agree with the analysis by Maraval (Intoduction, SCh 178, 38) that the name "Annisa" must have been neutrum in plural like today Chania or a lot of Greek towns. 
in $375 / 376$ where he was staying when he wrote the letter ${ }^{87}$ and where according to VSM Macrina should have been the leader of a group of women for approximately 20 years. Basil passed Macrina over in his letter 223 to Eustathius of Sebastea alluding to many visits of Eustathius to the place near the river Iris (Annisa was located nearby), where Basil stayed with his brother Gregory. Finally, Basil did not address to Macrina even a single one of his more than 300 letters, 13 of which were addressed directly to women and some concerned women.

If anybody suspects that Basil was a misogynist and that was a reason he did not say anything about his sister, I reply in advance: it is not true. He was truly devoted to his mother and grandmother; in letters 205 and 223, he emphasised their role in his life by belittling achievements of his father and grandfather mentioned, on the other hand, by Gregory of Nazianzus ${ }^{88}$.

\section{Gregory of Nazianzus}

In epitaph 54, in memory of Emmelia, Gregory of Nazianzus described her children as follows: sons and daughters, both married and unmarried, three famous

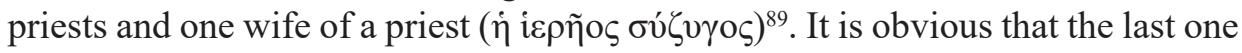
was Theosebia, honoured in epitaph 123 and called there the child of the famous

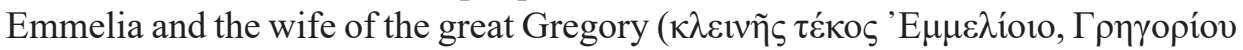

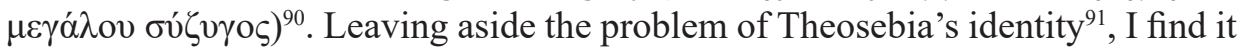
puzzling that in his epitaph 54 on Emmelia among the children of Emmelia Gregory of Nazianzus favoured the wife of a priest (Theosebia) over the leader of asceticism in Pontus (Macrina).

Further, Gregory of Nazianzus did write a consolation letter to Gregory of Nyssa after Theosebia (no matter, sister or wife) died ${ }^{92}$, but he did not write any in connection with Macrina's passing away. We do have another consolation letter of him addressed to Gregory of Nyssa on the occasion of Basil's death, in which he justifies himself that he had not come to Basil's funeral due to "the serious and

87 A.M. Silvas, Macrina the Younger, op. cit., 45.

${ }_{88}$ Gregory of Nazianzus, Oratio 43, 5 and 12 (In laudem Basilii Magni Caesareae in Cappadocia episcopi), PG 36, 500 and 509.

89 Gregory of Nazianzus, Epitaphium 54, PG 38, 37-38 = epigram VIII 161, in Anthologie palatine.

90 Gregory of Nazianzus, Epitaphium 123, PG 38, 77 = epigram VIII 164, in Anthologie palatine.

91 J. Daniélou (Le mariage de Grégoire de Nysse et la chronologie de sa vie, "Revue des études augustiniennes" 2 (1956), 71-78) thought there were two Theosebias, both married to Gregories: one daughter of Emmelia, sister of Gregory of Nyssa and Basil, married to certain Gregory, and another one, wife of Gregory of Nyssa. S. Elm (Virgins of God, op. cit., 157, footnote 64) claims that there might have been only one Theosebia, sister of Gregory of Nyssa and Basil, and бú may mean here associate or collaborator; the same argument was repeated by Silvas, Macrina the Younger, 7, footnote 25.

92 Gregory of Nazianzus, Epistula 197, 5-6; PG 37, 321-324. 
dangerous illness" ${ }^{93}$. If soon after that Macrina, sister of Gregory of Nyssa and Basil, died (according to $V S M^{94}$ ), we could have expected similar letter. Unless Gregory of Nazianzus suddenly recovered and attended her funeral; but that would have been stressed in VSM, since Gregory named among the participants of the funeral an unknown bishop Araxios ${ }^{95}$, he surely would have mentioned his famous friend, if he had been present.

\section{Histories of the Church}

Macrina does not appear in any Ancient sources describing the Church history of that period. Certainly, Ancient historians focused on relationships between the Church and the state, doctrinal disputes and bishops, but they also said something about the monastic life. And in none of that texts there is any mention of Macrina, alleged inspirer and leader of monastic life in Pontus according to VSM.

Macrina should have been evoked at least twice in the Historia Ecclesiastica by Sozomenus. When describing the beginnings of monasticism in Pontus and the vicinities he points to Eustathius of Sebastea as an initiator ${ }^{96}$ and later on Basil the Great as his continuator ${ }^{97}$. Socrates Scholasticus regarded Eustathius explicitly as a heretic ${ }^{98}$ and yet he says nothing about Macrina; according to him the founder of monasticism in Pontus was Basil ${ }^{99}$. He mentioned by name two brothers of Basil: Gregory of Nyssa and Peter, adding that only Peter followed Basil in monastic lifestyle ${ }^{100}$ - again, no mention about Macrina. Similarly, Rufinus said that Basil was the founder of monasticism in Pontus ${ }^{101}$ and had two brothers: Gregory of Nyssa and Peter ${ }^{102}$, failing to mention their saint sister.

\section{MACRINA THE YOUNGER - A LITERARY CONSTRUCT}

None of the writings about Macrina had as its aim to report historical events; they are full of literary topoi, rhetoric, quotations from the Bible. Even if they contain some information that seems historical, they are often incoherent and

93 Gregory of Nazianzus, Epistula 76; PG 37, 140-141.

94 GNO 8/1, 385.22-387.3.

95 GNO 8/1, 407.14-15.

96 Sozomenus, Historia Ecclesiastica III 14, PG 67, 1077-1081.

97 Sozomenus, Historia Ecclesiastica IV 17, PG 67, 1336.

98 Socrates Scholasticus, Historia Ecclesiastica II 39, PG 67, 333; II 43, PG 67, 352-353; IV 12, PG 67, 484.

99 Socrates Scholasticus, Historia Ecclesiastica IV 26, PG 67, 532.

${ }^{100}$ Socrates Scholasticus, Historia Ecclesiastica IV 26, PG 67, 533-536.

${ }^{101}$ Rufinus of Aquileia, Historia Ecclesiastica II 9, PL 21, 518C.

${ }^{102}$ Rufinus of Aquileia, Historia Ecclesiastica II 9, PL 21, 520C. 
contradictory. On the other hand, we have no external sources that confirm Macrina's achievements. Macrina described in VSM is obviously a literary construct.

\section{Inventing a saint}

Macrina became a part of a long tradition of fictitious women guiding men into mysteries of philosophy and true wisdom: Diotima from Plato's Symposium, Rhoda from The Shepherd of Hermas, 11 women from Methodius of Olympus' Symposium. She was also not the first fictional ascetic. In the middle 370s Jerome wrote Vita beati Pauli monachi Thebani, the life of the first eremite. Since 1877 many scholars have claimed that it is a life of a completely fictional character ${ }^{103}$. The hagiography was written in Latin, but it was translated into Greek and spread widely in the East as well as in the West ${ }^{104}$. Even if it had not been translated into Greek before VSM, Jerome could have told about it personally to both Gregories when he was in Constantinople in the years 380-381 as a student of Gregory of Nazianzus.

If Macrina as described in $V S M$ was not a real person, it is obvious that she was invented by the author of VSM - Gregory of Nyssa. However, he had co-plotters. The first one, certainly, was Gregory of Nazianzus, who supported Gregory of Nyssa's invention by writing the epitaph on Macrina. Secondly, both could have been backed up by Jerome during his stay in Constantinople.

\section{Macrina as a substitute for Eustathius of Sebastea}

The complete absence of Macrina in the Historiae Ecclesiasticae written in the $5^{\text {th }}$ century seems to confirm that she obviously was not the founder and leader of asceticism or monasticism in Pontus. The founder and inspirer of monasticism in Pontus was Eustathius of Sebastea. He became also an inspiration for Basil to start leading ascetic life. The analysis of Basil's correspondence proves that Basil and Eustathius had a close relationship for many years ${ }^{105}$. Already Sozomenus (Histo-

${ }^{103}$ S. Rebenich, Inventing an Ascetic Hero. Jerome's Life of Paul the First Hermit, in Jerome of Stridon. His Life, Writings and Legacy, eds. A. Cain - J. Lössl, Routledge, New York 2009, 14-16; T.D. Barnes, Early Christian Hagiography and Roman History, op. cit., 172.

104 J.N.D. Kelly, Jerome, his Life, Writings and Controversies, Hendrickson Pub, London 1975, 60; K. Jażdżewska, Hagiographic Invention and Imitation: Niketas'Life of Theoktiste and Its Literary Models, "Greek, Roman and Byzantine Studies" 49 (2009), 269.

${ }^{105}$ D. Amand, L'ascèse monastique de Saint Basile: Essai historique, Maredsous 1949, 52-61; J. Gribomont, Le monachisme au IVe siècle en Asie Mineure: de Gangres au Messalianisme, "Studia Patristica" 2 (1957), 400-415; J. Daniélou, Grégoire de Nysse et le messalianisme, "Recherches de Science Religieuse" 48 (1960), 119-134; Y. Courtonne, Un témoin du IVe siècle oriental: Saint Basile et son temps d'après sa correspondance, Les Belles Lettres, Paris 1973, 179-222; C.A. Frazee, Anatolian Asceticism in the Fourth Century: Eustathios of Sebastea and Basil of Caesarea, "Catholic Historical Review" 66 (1980), 16-33; G. Dagron, Les Moines et la ville: le monachisme à Constantinople jusqu'au concile de Chalcédoine (451), "Travaux et 
ria ecclesiastica III 14) reported that some considered Eustathius to be the author of the ascetic book attributed to Basil and some analyses do indicate Eustathius' influence on Basil's ascetical writings ${ }^{106}$.

In my opinion, Macrina was invented in order to substitute the heretic Eustathius in the life of Basil. Actually, it is not really my idea (apart from Macrina being invented). Already in 1959, J. Gribomont noticed the contradiction between descriptions of Basil's conversion and explained that VSM passes over Eustathius as since 375 he was openly a pneumatomachos ${ }^{107}$. In reality, not the year 375 is crucial in that story, but 381. The First Council of Constantinople condemned all who had signed the pneumatomachian confession of 375 and had not withdrawn therefrom. Actually, Eustathius signed many heretic confessions of faith during his life and then he withdraw from all of them. This time it was impossible. Eustathius died before the Council.

So, the situation was as follows: Basil was dead ( 378 or $\left.379^{108}\right)$ and the inspirer of his ascetic life was just condemned by the Council for the Trinitarian heresy (381). The matter of inspiration, of the master-pupil relationship, was something of crucial importance for the people of that time. If the inspirer of Basil's asceticism had been heretic, the entire work of Basil would have been questioned. It is worth stressing that it was not the first story of a substituted inspirer. First was Paul the Eremite (Vita beati Pauli monachi Thebani) who substituted Antony (VA) as a founder of monasticism ${ }^{109}$; we do not know whether Jerome did it because of personal ambition, conflict with Athanasius or more sublime reason like presenting another model of monastic life ${ }^{110}$. Anyway, Vita beati Pauli by Jerome confirms the importance of the beginnings of asceticism and sets up the precedent of substitution of one leader and master for another.

Mémoires" 4 (1970), 248-252; P. Rousseau, Basil of Caesarea, University of California Press, Berkeley - Los Angeles - London 1998, especially 9-10, 73-76, 239-245; F. Fatti, Monachesimo anatolico. Eustazio di Sebastia e Basilio di Cesarea, op. cit., 53-91.

${ }^{106}$ F. Loofs, Eustathius von Sebaste und die chronologie der Basilius-briefe. Eine patristische studie, Max Niemeyer, Halle 1898, 97; W.K. Lowther Clarke, St Basil the Great: A Study in Monasticism, Cambridge University Press, Cambridge 1913, 160-162; S. Elm, Virgins of God, op. cit., 134-135 and 212.

${ }^{107}$ J. Gribomont, Eustache le philosophe et les voyages du jeune Basile de Césarée, 123. The idea is present also in P. Maraval, Intoduction, SCh 178, 52 and S. Elm, Virgins of God, op. cit., 135.

${ }^{108}$ Regarding the date of Basil's death for the very good summary of the discussion see A.M. Silvas, Macrina the Younger, op. cit., 50.

109 Jerome attested that openly at the very beginning of his Vita beati Pauli monachi Thebani (SCh 508, 144-146; transl. NPNF II 6, 404): "It has been a subject of wide-spread and frequent discussion what monk was the first to give a signal example of the hermit life. [...] So then inasmuch as both Greek and Roman writers have handed down careful accounts of Antony, I have determined to write a short history of Paul's early and latter days".

${ }^{110}$ S. Rebenich, Inventing an Ascetic Hero, op. cit., 20-23. 
The absence of Macrina in Historiae Ecclesiasticae, incoherencies in the Macrina writings, and contradictions between the Macrina writings and other sources in addition to complete silence about Macrina in the letters of Basil and Gregory of Nazianzus make me advance a thesis that Macrina as described by Gregory of Nyssa is a literary construct aimed at substituting the condemned Eustathius by a saint ascetic sister in the life and work of recently deceased Basil. The fictional Macrina protected not only Basil, but also the entire monasticism in Pontus from the accusation to have been inspired at the very beginning by Eustathius of Sebastea, the heretic condemned posthumously for the Trinitarian dissent.

I would like to express my utmost gratitude for the support and important feedback that allowed me to express my thesis more precisely to: Jan M. Kozłowski, $\mathrm{PhD}$, Prof. Ewa Wipszycka, Katarzyna Jażdżewska, PhD, Prof. Tomasz Stępień, Karolina Kochańczyk-Bonińska, PhD and Małgorzata Jesiotr, PhD.

\section{References}

Alexandre M., Á propos du recit de la mort d'Antoine. L'heure de la mort dans la littérature monastique, in: Le temps chrétien de la fin de l'Antiquité au Moyen Age (IIIe-XIIIe siecles), ed. J.M. Leroux, CNRS Éditions, Paris 1984, 263-282.

Altaner B., Précis de patrologie, Editions Salvator, Paris 1961.

Amand D., L'ascèse monastique de Saint Basile: Essai historique, Éditions de Maredsous, Maredsous 1949.

Anthologie palatine, ed. P. Walz, Les Belles Lettres, Paris 1944.

Athanase d'Alexandrie, Vie d'Antoine, ed. G.J.M. Bartelink, SCh 400, Les éditions du Cerf, Paris 1994.

Barnes T.D., Athanasius and Constantius: Theology and Politics in the Constantinian Empire, Harvard University Press, Cambridge 2001.

Barnes T.D., Early Christian Hagiography and Roman History, Mohr Sieback, Tübingen 2010.

Basile, Lettres, ed. Y. Courtonne, Les Belles Lettres, Paris 1957, vol. 1-3.

Brakke D., Athanasius and the Politics of Asceticism, Oxford University Press, Oxford 1995.

Cameron A., Dialoguing in Late Antiquity, "Hellenic Studies Series" 65, Washington DC 2014, <http://chs.harvard.edu/CHS/article/display/5495> (24.2.2017).

Clark E.A., Holy Women, Holy Words: Early Christian Women, Social History and the "Linguistic Turn", "Journal of Early Christian Studies" 6 (1998), 413-430. 
Courtonne Y., Un témoin du IVe siècle oriental: Saint Basile et son temps d'après sa correspondance, Les Belles Lettres, Paris 1973.

Dagron G., Les Moines et la ville: le monachisme à Constantinople jusqu'au concile de Chalcédoine (451), "Travaux et Mémoires" 4 (1970), 229-276.

Daniélou J., Le mariage de Grégoire de Nysse et la chronologie de sa vie, "Revue des Études Augustiniennes" 2 (1956), 71-78.

Daniélou J., Grégoire de Nysse et le messalianisme, "Recherches de Science Religieuse" 48 (1960), 119-134.

Delehaye H., Les légendes hagiographiques, Société des Bollandistes, Bruxelles 1906.

Delehaye H., Les passions des martyrs et les genres littéraires, "Subsidia Hagiographica" 13, Bruxelles 1966.

Diekamp F., Die Wahl Gregors von Nyssa zum Metropoliten von Sebaste im Jahre 380, "Theologische Quartalschrift" 90 (1908), 384-401.

Elm S., Virgins of God: The Making of Asceticism in Late Antiquity, Clarendon Press, Oxford 1994.

Fatti F., Monachesimo anatolico. Eustazio di Sebastia e Basilio di Cesarea, in Monachesimo orientale. Un'introduzione, ed. G. Filoramo, Morcelliana, Brescia 2010, 53-91.

Festugière A.J., Vraisemblance psychologique et forme littéraire chez les anciens, "Philologus" 102 (1958), 21-42.

Frazee C. A., Anatolian Asceticism in the Fourth Century: Eustathios of Sebastea and Basil of Caesarea, "Catholic Historical Review" 66 (1980), 16-33.

Grégoire de Nysse, Lettres, trad. P. Maraval, SCh 363, Les éditions du Cerf, Paris 1990.

Gregorio di Nissa, Epistole, trad. R. Crisculo, Città Nuova, Napoli 1981.

Gregorius Nyssenus, De anima et resurrectione, ed. A. Spira, GNO 3/3, Brill, Leiden-Boston 2014.

Gregorius Nyssenus, Episulae, ed. G. Pasquali, Brill, GNO 8/2, Leiden 1989.

Gregorius Nyssenus, Vita sanctae Macrinae, ed. V. Woods Callahan, in Opera ascetica, GNO 8/1, Brill, Leiden 1952, 370-414.

Gregory of Nyssa, The Letters. Introduction, Translation and Commentary, transl. A.M. Silvas, Brill, Leiden-Boston 2007.

Gregorius Theologus, Epigrammata, PG 38, 81-113.

Gregorius Theologus, Epistolae, PG 37, 21-387.

Gribomont J., Eustathe le philosophe et les voyages du jeune Basile de Césarée, "Revue d'histoire ecclésiastique" 54 (1959), 115-124.

Gribomont J., Le monachisme au IVe siècle en Asie Mineure: De Gangres au Messalianisme, "Studia Patristica" 2 (1957), 400-415.

Helleman W.E., Cappadocian Macrina as Lady Wisdom, "Studia Patristica" 37 (2001), 86-102. 
Heussi K., Der Ursprung des Mönchtums, Scientia Verlag, Tübingen 1936.

Hoffmann M., Der dialog bei den christlichen Schriftstellern der ersten vier Jahrhunderte, Akademie-Verlag, Berlin 1966.

Hösle V., Der philosophische Dialog: Eine Poetik und Hermeneutik, C.H. Beck, Munich 2006.

Jażdżewska K., Hagiographic Invention and Imitation: Niketas' Life of Theoktiste and Its Literary Models, "Greek, Roman, and Byzantine Studies" 49 (2009), 257-279.

Kahn C., Plato and the Socratic Dialogue: The Philosophical Use of a Literary Form, Cambridge University Press, Cambridge 1996.

Kardong T.G., Who was Basil's mentor? Part 1, "American Benedictine Revue" 60 (2009), 183-201.

Kardong T.G., Who was Basil's mentor? Part 2, "American Benedictine Revue" 60 (2009), 299-309.

Karfiková L., Gregory of Nyssa, Witness of Macrina's Life and Death, "Theologica Olomucensia" 14 (2013), 15-26.

Kelly J.N.D., Jerome, his Life, Writings and Controversies, Hendrickson Pub, London 1975.

Kozłowski J.M., Pionius Polycarpi imitator: References to Martyrium Polycarpi in Martyrium Pionii, "Science et Esprit" 67 (2015), 417-434.

Kozłowski J.M., Tanto perfusus est sanguine, ut... Dependence of Passio Perpetuae 21,1-3 upon Martyrium Polycarpi 14,2 and 16,1, "Eirene. Studia Graeca et Latina” 52 (2016), 387-395.

Krueger D., Writing and the Liturgy of Memory in Gregory of Nyssa's Life of Macrina, "Journal of Early Christian Studies" 8 (2000), 483-510.

Loofs F., Eustathius von Sebaste und die chronologie der Basilius-briefe. Eine patristische studie, Max Niemeyer, Halle 1898.

Lowther Clarke W.K., St Basil the Great: A Study in Monasticism, Cambridge University Press, Cambridge 1913.

Luck G., Notes on the Vita Macrinae, in The Biographical Works of Gregory of Nyssa, Proceedings of the Fifth International Colloquium on Gregory of Nyssa, Mainz, 6-10 September 1982, ed. A. Spira, The Philadelphia Patristic Foundation, Cambridge 1984, 21-32.

Maraval P., Encore les frères et soeurs de Grégoire de Nysse, "Revue d'histoire et de philosophie religieuses" 60 (1980), 161-166.

Maraval P., La Vie de sainte Macrine de Grégoire de Nysse: continuité et nouveauté d'un genre littéraire, in Du héros païen au saint chrétien. Actes du colloque organisé par le Centre d'Analyse des Rhétoriques Religieuses de l'Antiquité (C.A.R.R.A.) Strasbourg, 1er-2 décembre 1995, eds. G. Freyburger et L. Pernot, Brepols Publishers, Paris 1997, 133-138. 
Maraval P., Intoduction, in Vie de sainte Macrine, SCh 178, Les éditions du Cerf, Paris 1971, 19-133.

Mateo-Seco L.F., Macrina, in The Brill Dictionary of Gregory of Nyssa, eds. L.F. Mateo-Seco - G. Maspero, Brill, Leuven 2010, 471-474.

Mateo-Seco L.F., Vita Macrinae, in The Brill Dictionary of Gregory of Nyssa, eds. L.F. Mateo-Seco - G. Maspero, Brill, Leuven 2010, 469-470.

McGuckin J., Macrina, in Encyclopedia of Monasticism, ed. W.M. Johnston, vol. 2, Taylor \& Francis, Chicago - London 2000, 801.

Momigliano A., The Life of St. Macrina by Gregory of Nyssa, in On Pagans, Jews, and Christians, Wesleyan, Middletown 1987, 206-221.

Pfister J.E., A biographical note: The Brothers and Sisters of St. Gregory of Nyssa, "Vigiliae Christianae" 18 (1964), 108-113.

Pouchet J.R., Basile le Grand et son univers d'amis d'après sa correspondance: une stratégie de communion, Institutum Patristicum Augustinianum, Roma 1992.

Quasten J., Patrology, vol. 3, Resources for Christian Living, Allen 1983.

Radde-Gallwitz A., Basil of Caesarea. A guide to his life and doctrine, Wipf \& Stock Pub Eugene 2012.

Ramelli I., Saggio introduttivo, in Gregorio di Nissa, Sull'anima et resurrezione, RCS Libri, Milano 2007, 5-341.

Rebenich S., Inventing an Ascetic Hero. Jerome's Life of Paul the First Hermit, in Jerome of Stridon. His Life, Writings and Legacy, eds. A. Cain - J. Lössl, Routledge, New York 2009, 13-27.

Rousseau P., Basil of Caesarea, University of California Press, Berkeley - Los Angeles - London 1998.

Rubenson S., Letters of St. Antony: Monasticism and the Making of A Saint, Trinity Press Int'1, Minneapolis 1995.

Sauget J.M., Macrina la Giovane, in Bibliotheca Sanctorum, vol. 8, Città Nuova, Roma 1996.

Silvas A.M., Macrina the Younger. Philosopher of God, Brepols Publishers, Turnhout 2008.

Silvas A.M., The Asketikon of St Basil the Great, Oxford University Press, Oxford - New York 2005.

Voss B.R., Der dialog in der frühchristlichen Literatur, Wilhelm Fink Verlag, München 1970.

Wessel S., Memory and Individuality in Gregory of Nyssa s De anima et resurrectione, "Journal of Early Christian Studies" 18 (2010), 369-392.

Wipszycka E., Drugi dar Nilu, Tyniec. Wydawnictwo Benedyktynów, Kraków 2014.

Wipszycka E., Wstęp, in Atanazy Aleksandryjski, Żywot świętego Antoniego, Instytut Wydawniczy PAX, Warszawa 1987, 31-54. 


\begin{abstract}
Summary
Scholars usually treat writings about Macrina the Younger as sources of information about historical events and persons. In my opinion, all four sources about Macrina were written according to the rules of literary genres that do not have as their objective to report history but have other purposes such as edification, polemics or honouring somebody. In addition to that, Macrina did not appear in many other sources in which she should have been mentioned if she had been an inspirer and leader of monasticism in Pontus. I think that Macrina, as described by Gregory of Nyssa and Gregory of Nazianzus, was invented by them in order to substitute the true inspirer and leader of asceticism in Pontus - Eustathius of Sebastea.
\end{abstract}

Keywords: Gregory of Nyssa, Macrina the Younger, Eustathius of Sebastea, hagiography, monasticism

Makryna Młodsza - wymyślona święta

\title{
Streszczenie
}

Dzieła dotyczące Makryny Młodszej badacze traktują zwykle jako skarbnicę informacji na temat historycznych wydarzeń i osób. Moim zdaniem jednak każde z tych czterech pism zostało napisane zgodnie z zasadami gatunków literackich, których celem nie było i nie miało być opisywanie historii, ale które miały zupełnie inne zadania, takie jak zachęta moralna, polemika czy uhonorowanie kogoś. Z drugiej strony Makryna Młodsza nie pojawia się w wielu innych źródłach, w których z pewnością zostałaby wspomniana, gdyby rzeczywiście była inspiratorką i liderką monastycyzmu w Poncie. Sądzę, że Makryna opisana przez Grzegorza z Nyssy i Grzegorza z Nazjanzu została przez nich wymyślona po to, by zastąpić prawdziwego inspiratora i lidera ascetyzmu pontyjskiego - Eustacjusza z Sebasty.

Słowa kluczowe: Grzegorz z Nyssy, Makryna Młodsza, Eustacjusz z Sebasty, hagiografia, monastycyzm 